\title{
Central Bank in the Function of Development of National Economy of Bosnia and Herzegovina
}

\author{
Ph.D. Zoran Mastilo ${ }^{1, a^{*}}$, Nenad Božovićb ${ }^{\text {, Dejan Mastilo }}$,cc \\ ${ }^{1}$ Associate Professor, Faculty of Business Economics, University of East Sarajevo, Bosnia and \\ Herzegovina \\ ${ }^{2}$ Research associate at Oikos institute, Research centre in Bijeljina, Bosnia and Herzegovina \\ azoran.mastilo1964@gmail.com, bnenadbzvc@gmail.com, cnovi.economics.institut@gmail.com
}

Keywords: Currency boards, Economic growth, Monetary Policy, Correlation Analysis, Transition Economy.

\begin{abstract}
The paper addresses and evaluates the currency boards' policy and assesses whether the economic development of Bosnia and Herzegovina is the function of currency boards, as a form of monetary policy. In this context, a hypothesis that the currency boards provides the foundation for growth and development of a transition economy is being put to the test. To test the hypothesis, the paper compares the movement of economic growth indicators (gross domestic product) among the countries of South Eastern Europe with the primary focus on Bosnia and Herzegovina. By comparing the obtained results, as well as by applying the correlation and regression analysis, by means of simple linear regression, it is proven that the currency boards do not represent an obstacle to economic growth, but is the basis for establishing the stability of the economy and the basis for sustainable growth and development able to adequately respond to shocks.
\end{abstract}

\section{Introduction}

Central banks are distinctive independent monetary institutions, whose main tasks are the regulation of the monetary and credit system with the overall economic policy and whose main business goals are not the maximization of profit, but price stability and achievement of the highest prosperity level of the state. The IMF also includes the currency boards under the notion of Central Bank, as well as dedicated state agencies that perform the central bank activities in extraordinary situations. The Central Bank of Bosnia and Herzegovina (hereinafter referred to as $\mathrm{CBBH}$ ) operates under the currency boards principles. In doing so, it does not create a currency without backing and cannot lend funds to the government nor give loans to commercial banks as a "lender of last resort", it is not allowed to execute open market operations and cannot use the exchange rate to resolve economic problems in the country.

The monetary policy implemented by the central bank certainly has an impact onto the economic growth and the development of the respective economy. Central banks most frequently place maintenance of price stability through controlling the supply of money as the primary goal of their policy. In that case, monetary policy has a stabilizing role and an impact on economic growth through numerous channels. The framework, the role or the level of freedom that a central bank has in monetary policy implementation can be limited by certain primary objectives of monetary policy, the nature of the transmission mechanism of monetary policy, as well as by other factors, including the uncertainties that may occur in the economy.

One of the forms of monetary policy that the central bank may implement is the currency boards' policy. With this policy, the central bank loses all of its discretionary powers and acts according to strictly established rules that are reduced to maintaining a fixed exchange rate in relation to the chosen anchor currency. In such policy, the central bank is tasked with the primary objective of maintaining a fixed exchange rate, thus indirectly affecting the price stability in the economy. 
However, since the central bank loses its discretionary powers through such policy, it is often questioned whether such a monetary policy system stimulates economic growth or acts in a destabilizing manner towards the economic growth?

Bosnia and Herzegovina is one of the countries that apply the currency board's policy. According to the results of the implementation of such system to this day, it can be said that the currency boards have managed to maintain a stable domestic currency and that the basis for stable economic growth has been established. Nevertheless, in spite of the positive results of the currency boards, it is often a subject of criticisms mainly aimed at the fact that a fixed exchange rate does not benefit the domestic economy, that it affects exports in an adverse manner, thus negatively influencing the economic growth and development. Under such circumstances, it is useful to explore the results of growth and development of other countries, such as the neighbouring countries, and on those findings, assess the extent to which the currency boards really affect the economic growth and development in a negative manner.

The subject of this paper is to investigate whether the currency boards of the countries of Southeast Europe (Bulgaria and Bosnia and Herzegovina) has positively influenced economic growth and development or if it had a destabilizing effect. In the context of the subject matter, theoretical frameworks and research findings on the currency boards, its role, importance as well as the effects are investigated. In particular, the development, growth and development trends in SEE countries are analysed in order to assess the effect of the currency boards in the assessed countries.

The aim of the paper is to analyse the correlation between the currency boards and the economic growth in order to assess the central bank's influence on the development of the Bosnia and Herzegovina's national economy. The uniqueness of the paper stems from the fact that the research is based on the application of modern tools in order to analyse the issues of currency boards in the context of contributions to the development of the economies in transition.

\section{Methodological Framework}

The research methods used in the paper are the comparative method, the correlation and regression method. The comparative method was applied when comparing the real GDP growth rates of the Southeast Europe countries in the period from 2005 to 2018. The correlation method was applied in the empirical section of the paper. This statistical method measures and assesses the level of correlation between the economic growth and indicators of monetary policy in Bosnia and Herzegovina. It assesses the existence and the type of correlation among the currency board's variables, economic growth and development variables and the foreign trade position variables of the economy.

The simple linear regression method is also applied in the empiric part of the paper. The regression was used to measure the impact and strength of the relationship between the currency board's variable and the economic growth variable, expressed through GDP. A linear regression formed a model that can predict the movement of GDP in relation to the currency board's parameter. In the theoretical section of the paper, an analysis method was used to analyse the notion, role and importance of the currency boards, its pros and cons, as well as the synthesis method which summarized the results of the research performed by other authors who analysed this topic.

A fundamental hypothesis is defined in the research. It reads as follows: The currency boards provide the basis for the growth and development of the transition economy. The given hypothesis is tested thusly:

- the currency board variable is measured through two indicators: foreign exchange reserves and the broadest monetary aggregate; in Bosnia and Herzegovina, this is M2; 
- the economic growth variable is measured through nominal GDP, gross savings and inflation;

- the foreign trade position is measured through two indicators: current account balance and FDI (Foreign Direct Investment).

\section{Literature Review}

The distinctive features of currency boards that were first established in British colonies in the second half of the nineteenth century included their issue of local coin and notes at a fixed exchange rate with a foreign money, usually British sterling. Currency boards held reserves equal to at least 100 percent of their currency liabilities, some in the form of interest-bearing assets denominated in the foreign money, on which they earned seigniorage [1]. Currency boards are a strong form of fixed exchange rate regime where all currency on issue is fully backed by assets denominated in the anchor currency. The traditional form originated in the 19th century and were common in colonies. While generally successful, most were replaced by central banks. Modern currency boards, notably Hong Kong, are operated by institutions resembling central banks in sophisticated financial systems. Virtual currency boards, such as Libra, are private institutions issuing a type of cryptocurrency known as 'asset backed stablecoins'. All face a challenge from extraordinarily low interest rates [2].

The historical evidence suggests that currency boards succeeded in maintaining exchange rate stability and facilitating trade, at the cost of tying up reserves and restricting the scope for monetary policy, with more ambiguous evidence on their broader economic impact. Exits were generally to pegged regimes and proceeded smoothly. A more recent group of currency boards was motivated by stabilization rather than trade considerations. While the sample is small, the lesson from their experience is straightforward (and unsurprising). Boards deliver short-term stabilization and an extended honeymoon period. Whether stability lasts depends on policy choices during the honeymoon period. Countries using the good times to achieve lasting fiscal balance while vigilantly counteracting real appreciation and prudently managing capital inflows stand to reap longer-term benefits at modest costs [3].

Monetary policy in the currency board is such that there are no discretionary powers. In the currency board arrangement, the central bank, as the monetary authority, has no influence on the supply of money - as the market forces determine the supply and demand of money in circulation. Changes that occur in respect of the money demand are adjusted to endogenous changes in international reserves through the balance of payments rather than variations in net domestic assets, which would otherwise occur with a framework that implies a central bank arrangement [4].

The Currency Boards cannot approve a loan to the state, to the banking sector or to any other entity. The currency board reserves are low-risk bonds that bear interest and other assets expressed in the anchor currency. The currency boards make a profit on the difference between the interest on its reserve assets and the cost of maintaining its obligations - the necessity to cover the costs and to maintain its reserves at the mandatory level as specified by law. The true currency boards lack the freedom to decide on monetary policy - the market forces alone determine the money stock [5].

The Currency Boards have certain features used for interpretation and analysis, and according to which it brings certain effects to the economy. Convertibility is the first feature of the currency boards. If a state introduces a currency board, it therefore allows unlimited convertibility of the local currency for the anchor currency at the fixed exchange rate determined by law. Deposits in domestic currency will not be automatically transferred to foreign currency (anchor currency), but the arbitration conditions between local deposits and reserve currency are determined through established exchange rate. Another key feature of the currency boards is the foreign exchange reserves. The currency board arrangement holds high-quality securities and other high-quality instruments, such as gold. It is necessary for the currency boards to have $100 \%$ coverage of the monetary base with foreign 
reserves, but this coverage usually amounts to $105-110 \%$. The seignorage with the currency boards is achieved on the difference between the interest paid on the foreign exchange reserves and the expenses generated from issuing the currency. The currency boards transfer a portion of the profit to the government, whereas a portion is kept as its own capital. This distribution is regulated by law.

In the currency boards system, the central bank is unable to lend funds to the government or to any other sector of the state, and thus cannot broadcast fiduciary money. That is the exact reason why it cannot affect the inflation. Through the currency boards, taking into account this limitation, a strict budgetary restriction on public finances is promoted in which the expenditures are financed exclusively by collecting taxes and other public revenues or through commercial borrowing.

The Currency Board Agreement (CBA) represents an obligation to allow the issue of a certain amount of money against the purchased currency at a fixed exchange rate with no restrictions. In addition, the only method to increase the monetary base is by exchanging the national currency for foreign ones. Currency Board Arrangement operates in several post-socialist European economies as an alternative to traditional central banking. The CBA literature primarily focuses on the discipline of the fixed exchange rate, suggesting that the gain of reduced exchange rate volatility and monetary stability outweigh the loss of independent monetary policy. It does not address the role and impact of foreign ownership of the banking system on currency board dynamics. Through a case study of Bosnia and Herzegovina some authors suggest that monetary policy is not abandoned, it is decentralized and privatized and critical to the maintenance of financial stability of the CBA [6].

\subsection{Positive effects and results of the currency boards}

One of the primary advantages developed together with the currency boards are low inflation and lower interest rates, which is the product of the currency boards. Although the inflationary level in the economies applying the currency board system could remain higher than inflation in the anchor currency's country, the research confirmed that the level of inflation in the economy that applies the currency boards system is lower in relation to the economies applying the fixed foreign exchange rate regime [7]. The success in respect of the inflation was significantly better in the currency boards system, compared to other economies that apply fixed or fluctuating exchange rate regime.

From 1975 to 1996, the inflation averaged to about 6\% annually for countries that applied the currency boards, whereas that figure for other countries (with a fixed exchange rate) was $22 \%$, and about $43 \%$ for the countries with a fluctuating exchange rate [8]. The inflation movement is also influenced by the signal effect of fixing the exchange rate, as it is expected that the fixed exchange rate would to provide the private sector with transparent information, thusly benefiting the future inflation rate.

Some authors believe that the causes of low inflation lie within the activity of nominal anchors as well as in the effects of discipline [9]. Basically, the effect of a nominal anchor is such that inflation becomes exogenous. The effect of discipline, on the other hand, is maintained in the areas of monetary and fiscal policy - a slower increase in funds as well as the higher fiscal discipline are evident. Another effect appearing in this case is the effect of confidence. According to this effect, the demand for the domestic currency is increased for the given growth rates, which consequently leads to a decrease in inflation [10]. However, it is important to note that merely fixing of the exchange rate will not immediately lead to lower inflation, particularly if the fixed exchange rate is set at a low level or when the reserve currency depreciates against other currencies of the key trading partners of the anchor currency country. A higher average GDP growth per capita indicates that the effect of inflation, which in this case becomes superior, as shown in a survey that covered the period from 1975 to 1996, did not lead to lower economic growth [10]. More precisely, the average GDP growth per capita was actually twice as high as within the currency board arrangement compared to other fixed and fluctuating exchange rate regimes. 
In the currency boards system, the currency becomes stable. Currency boards generally opt, either by law or by the Constitution, for a full convertibility of the domestic currency to the reserve currency, and for the fixed exchange rate between domestic and reserve currency. In doing so, the uncertainty as well as the risks of nominal exchange rates are eliminated to the highest degree, positively influencing the international trade, investments and economic growth [11].

In the currency boards system, monetary and fiscal policies become more reliable. The currency boards are forbidden to finance the budget deficit, whereas the state is forced to implement an improved fiscal discipline, which contributes to strengthening of stability. Research has shown that fiscal deficits in countries with currency boards were significantly lower in comparison to the other foreign exchange rate regimes [7].

Taking into account the above mentioned advantages of the currency boards, it is fairly obvious that it is a model that is quite optimal for a small, open transition economy that seeks to strengthen its macroeconomic credibility and strives to tackle high inflation. However, this system also has certain shortcomings that should by no means be ignored [12].

\subsection{Shortcomings of the currency boards}

The currency boards also feature some shortcomings or disadvantages that must be taken into account. The first shortcoming is that there is a loss of discretionary monetary policy, as well as the loss of the application of foreign exchange rate instruments that can even out the balance of payment. Net export is a channel through which the output within the business cycle may be increased through the exchange rate.

The fixed exchange rate, and in particular the arrangement of the currency boards, are connected to the actual appreciation of the domestic currency, loss of competitiveness and deterioration of the trade account balance and current account balance [13]. However, the situation of greater capital mobility causes the link between the depreciation of the exchange rate and the impact on improvements in the current account, to become weaker, looser.

Some authors doubt that the central bank can effectively utilise discretionary policy in a situation of high capital mobility, as well as in the conditions of global financial markets [14]. In addition to these circumstances, the effect that foreign exchange rate depreciation has on real incomes may neutralize the stimulation of net exports growth. This effect will depend on the elasticity of trade flows in terms of prices and the reaction of trade prices to changes in the exchange rate. Depending on these circumstances, the currency boards would be a better solution for open economies as a monetary policy principle.

Certain authors consider that the currency board arrangement can provide a mechanism for adapting the balance of payments [15]. If a deficit in the balance of payments occurs in case of a fixed exchange rate, there is a decline in the money supply as the private sector converts the domestic currency into a foreign one to settle its obligations and liabilities abroad. Such a situation leads to an increase in the interest rate that will attract capital. A higher interest rate brings increased deflationary pressures, as the domestic absorption (as well as the import) is decreased, thusly improving the current account balance. Another way to overcome the current account deficit is the use of foreign sources, such as foreign direct investments or portfolio investments, the inflows of which maintain the equilibrium of payment balance. As for the export adjustment mechanism, when the prices are flexible and in case of registering a decline, such a situation influences the improvement of export. Thus, an effect that influences full employment is achieved, therefore resolving the deficit in the balance of payments through deflation. 
Such a mechanism of adjustment or harmonization relies on two important features of the currency boards: The first feature is the automatic reduction of money supply in case the balance of payments encounters a deficit. This is not a situation where monetary authorities seek to sterilize foreign exchange inflows. The second condition implies a basic assumption of wage and price flexibility. If there is no such assumption, then the nominal fixed exchange rate will be overvalued in real terms. Under the influence of a weaker money supply, there is an increase in interest rates which influences the occurrence of contraction in the economy. If there are external shocks, wage flexibility is also of great importance, as is the increase in the price of imported goods, which is of particular importance [12].

Another disadvantage occurring in the case of currency boards is the divergence between the monetary policy of a country applying the currency boards and a country whose currency is taken up as the anchor currency. When a country applies the currency boards, it then imports the monetary policy of a country whose currency it accepts as its anchor currency. Changes in the monetary policy of a country whose currency is embraces as an anchor currency may be inadequate for a country applying a currency boards in cases where the business cycles of the anchor currency country and the country applying the currency boards are mutually inconsistent. The inability of the currency boards to influence the appreciation or depreciation of the domestic currency in order to protect the economy, incurs certain costs, which may often be quite excessive.

Other risks that arise in connection with the currency board arrangement occur in the situation when the value of the reserve currency changes in relation to the currencies of other trading partners. The point is that the weakening of the reserve currency may substantially transfer the inflationary pressures onto the country applying the currency boards in the event of a stronger depreciation of the anchor currency relative to other currencies of its trading partners [16].

\section{Empirical Findings and Discussion}

In this Section, special attention is paid on nominal and real GDP in the countries of South Eastern Europe (SEE). Therefore, GDP is the best indicator of growth and economic development. Table 1 shows trends in the real GDP growth rates of SEE countries, the exchange rates applied and the movement of real GDP over the observed period. The greatest recession was noted in Croatia who applied a managed floating exchange rate and experienced a contraction of $7.38 \%$. Romania experienced a contraction of $7.07 \%$, while also applying the managed floating exchange rate policy.

It is also noteworthy to mention that the economies that do not apply the currency boards' policy continued to experience a rather low and negative growth in the years following the crisis, as is the case with Croatia and Serbia, recording a notable increase only in 2016.

Looking at the GDP growth in Bosnia and Herzegovina $(\mathrm{BH})$, it can be noted that the real GDP growth rate amounted to about $8 \%$ at the end of 2005 , only to drop to just about $3 \%$ today. The reason for the decline in real growth rates is predominantly to be found with the general global stagnation caused by the crisis, which $\mathrm{BH}$ was by no means immune to. This means that the decline in real GDP should not be perceived as an isolated occurrence, but in the light of global conditions, primarily in respect of the situation in the EU, which BH is closely related to, both monetary and in terms of foreign trade. During 2017, the GDP in Bosnia and Herzegovina maintained its growth level from 2016. Nevertheless, it is important to note that in 2017, industrial production registered an increase in all areas compared to the year before, particularly in the area of production and supply of electricity, gas and air conditioning [17, pp. 18]. 
Table 1. Real GDP growth rates of analysed countries from 2005 to 2018

\begin{tabular}{|c|c|c|c|c|c|c|c|c|}
\hline \multirow{2}{*}{ Year } & $\begin{array}{c}\text { Fluctuating } \\
\text { exchange } \\
\text { rate }\end{array}$ & \multicolumn{2}{|c|}{ Currency boards } & \multicolumn{3}{|c|}{$\begin{array}{c}\text { Managed floating } \\
\text { exchange rate }\end{array}$} & $\begin{array}{c}\text { Conventional } \\
\text { fixed } \\
\text { exchange rate }\end{array}$ & Dollarization \\
\cline { 2 - 9 } & Albania & Bulgaria & BH & Croatia & Serbia & Romania & Macedonia & Montenegro \\
\hline 2005 & 5,72 & 7,24 & 8,76 & 4,16 & 5,54 & 4,17 & 4,72 & 4,19 \\
\hline 2006 & 5,43 & 6,75 & 5,38 & 4,79 & 4,90 & 8,06 & 5,14 & 8,57 \\
\hline 2007 & 5,90 & 7,68 & 5,73 & 5,15 & 5,89 & 6,86 & 6,47 & 10,66 \\
\hline 2008 & 3,76 & 3,64 & 5,58 & 2,05 & 5,37 & 8,46 & 5,47 & 3,49 \\
\hline 2009 & 3,35 & $-3,59$ & $-2,99$ & $-7,38$ & $-3,12$ & $-7,07$ & $-0,36$ & $-5,80$ \\
\hline 2010 & 3,71 & 1,32 & 0,87 & $-1,70$ & 0,58 & $-0,80$ & 3,36 & 2,73 \\
\hline 2011 & 2,55 & 1,92 & 0,96 & $-0,28$ & 1,40 & 1,06 & 2,34 & 3,23 \\
\hline 2012 & 1,42 & 0,03 & $-0,82$ & $-2,19$ & $-1,02$ & 0,64 & $-0,46$ & $-2,72$ \\
\hline 2013 & 1,00 & 0,86 & 2,35 & $-1,06$ & 2,57 & 3,53 & 2,93 & 3,55 \\
\hline 2014 & 1,77 & 1,33 & 1,15 & $-0,49$ & $-1,83$ & 3,08 & 3,63 & 1,78 \\
\hline 2015 & 2,23 & 3,62 & 3,07 & 2,25 & 0,76 & 3,97 & 3,84 & 3,39 \\
\hline 2016 & 3,37 & 3,94 & 3,06 & 2,98 & 2,80 & 4,59 & 2,41 & 2,95 \\
\hline 2017 & 3,81 & 3,67 & 3,02 & 2,85 & 1,93 & 4,20 & 0,00 & 4,38 \\
\hline 2018 & $3,60^{*}$ & $3,50^{*}$ & $3,20^{*}$ & $2,60^{*}$ & $3,00^{*}$ & $3,60^{*}$ & $2,30^{*}$ & $4,80^{*}$ \\
\hline
\end{tabular}

Source: World Bank stats

*forecasted growth rates for 2018

Regardless of these positive results, the real rate of economic growth remained low. In any case, the progress achieved in economic growth, though very modest, is however a signal that the economy is being maintained [18]. Trends in the movement of GDP in Bulgaria have a similar path as the ones in Bosnia and Herzegovina. In 2009, Bulgaria recorded a recession, with its GDP registering a negative value of nearly $-4 \%$. In the following year, the economy managed to overcome the recession and continued the growth of real GDP, but at lower levels in comparison to the precrisis levels. The same as in Bosnia and Herzegovina, the GDP trend of Bulgaria should also be viewed in a global environment dominated by crisis conditions. In 2017, real growth in Bulgaria amounted to $3.6 \%$ and was primarily fuelled by increased exports, increased private consumption and changes in the volume of supplies. Somewhat lower capital investments of the government have influenced the reduction of total capital stocks, while private investments recorded growth [19]. Indicators on the movement of nominal and real GDP in the analysed economies applying the currency boards' policy show that, in spite of the severe crisis strikes recorded in 2009, the economies of both countries managed to recover, therefore maintaining the economic growth in line with the countries of the region and the EU countries (Report on Public Finances in EMU).

Through analysis and comparison of real GDP data, a conclusion can be made that the currency boards' policy did not represent a constraint in economic growth, measured against real GDP growth, since the growth trend recorded in countries applying the currency board was in line with the trend that was recorded in other countries of Southeast Europe.

Monetary aggregates are, in fact, monetary indicators used to determine the quality and function of money in the economy, but also to conduct monetary and liquidity policy of the economy and other sectors. Most authors who deal with this area consider that monetary aggregates include: Money supply (M1), Liquid assets (M2) and Total liquid assets (M3). In addition to the above, some authors include the following terms under the notion of monetary aggregates: Monetary supply (M4) and Monetary capacity (M5) [20]. Given that the broadest monetary aggregate in Bosnia and Herzegovina is M2, we shall explain in more detail the assets it covers. Monetary analysis and 
economic policy most frequently use the money supply aggregate (M1), in addition to which the monetary stock or primary money are often used. This aggregate is also called central bank money. It includes the following funds: currency in circulation (M0), bank accounts, petty cash, demand deposits, mandatory reserve of banks and reserve funds. In addition to the money supply, M2 aggregate also includes savings and other similar deposits, deposits with maturity period up to one year, short-term securities and short-term deposits of domestic customers in foreign currency. Table 2 shows the correlation analysis of the variables compared for $\mathrm{BH}$.

Table 2. Correlation Matrix for Bosnia and Herzegovina

\begin{tabular}{|c|c|c|c|c|c|c|c|}
\hline & $\begin{array}{c}\text { Foreign } \\
\text { exchange } \\
\text { reserves }\end{array}$ & GDP & $\begin{array}{c}\text { Gross } \\
\text { savings }\end{array}$ & FDI & M2 & Inflation & $\begin{array}{c}\text { Current } \\
\text { account }\end{array}$ \\
\hline $\begin{array}{c}\text { Foreign } \\
\text { exchange } \\
\text { reserves }\end{array}$ & 1,000 & & & & & & \\
\hline GDP & 0,750 & 1,000 & & & & & \\
\hline $\begin{array}{c}\text { Gross } \\
\text { savings }\end{array}$ & 0,548 & 0,018 & 1,000 & & & & \\
\hline FDI & 0,005 & $-0,215$ & 0,470 & 1,000 & & & \\
\hline M2 & 0,808 & 0,826 & 0,040 & $-0,429$ & 1,000 & & \\
\hline Inflation & $-0,573$ & $-0,252$ & $-0,182$ & 0,415 & - & 1,000 & \\
\hline $\begin{array}{c}\text { Current } \\
\text { account }\end{array}$ & 0,329 & 0,134 & 0,257 & $-0,385$ & 0,256 & $-0,682$ & 1,000 \\
\hline
\end{tabular}

Source: Author's own processing done in software suite MegaStat

The data obtained indicate the existence of a strong positive connection between the currency boards and GDP. Specifically, the correlation between foreign exchange reserves and GDP amounts to 0.75 , while amounting to 0.826 between M2 and GDP. Foreign exchange reserves are in a negative relation to inflation, meaning that the currency boards lead to an inflation decline in Bosnia and Herzegovina, as confirmed by a negative correlation of 0.62 between the inflation and M2. The currency boards had a positive impact on savings, thus making the correlation between foreign exchange reserves and savings 0.548 .

No significant connection was noted between the currency boards, the current account and FDI, and is therefore concluded that the currency boards in Bosnia and Herzegovina had no significant positive influence on the foreign trade position of Bosnia and Herzegovina.

The strongest connection among the data analysed is registered between the GDP and M2 and amounts to 0.826 . As this connection is the strongest one, a regression analysis was performed as a simple linear regression to investigate to what extent M2, as a currency board variable, affects the GDP movement, as a variable of economic growth. Figure 1 shows a scatter diagram for Bosnia and Herzegovina, which also shows that there is a positive linear connection between the broadest monetary aggregate in Bosnia and Herzegovina - M2, as a feature of the currency boards, and GDP, which reflects economic growth. 


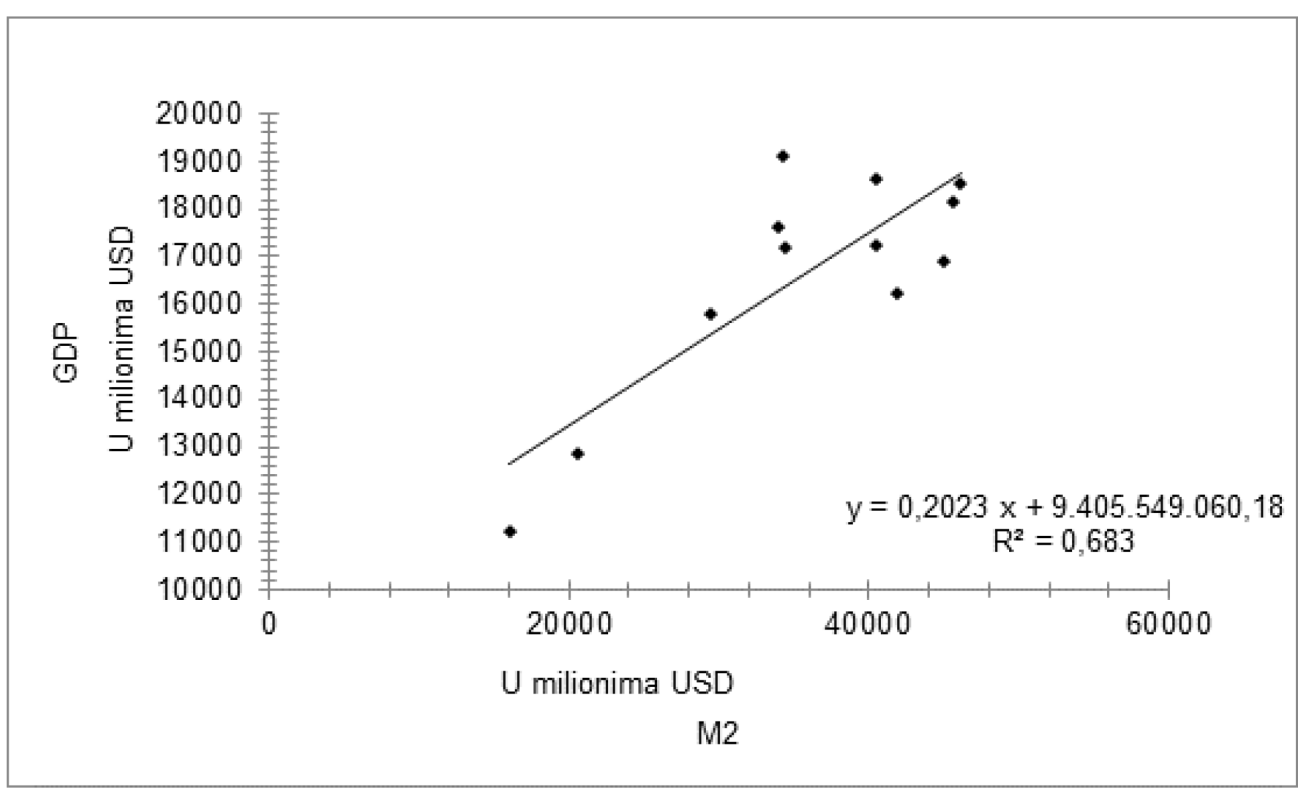

Figure 1. Scatter diagram for Bosnia and Herzegovina Source: Author's processing in the software suite MegaStat

It has been shown that there is a strong correlation between the independent variable - the currency board M2, and the dependent variable - GDP, which is also confirmed by the coefficient of determination, which amounts to $68.3 \%$. This means that changes in M2 of $68.3 \%$ explain changes in GDP.

The regression results shown in Table 3 show that the regression model is reliable for estimating and forecasting the impact of M2 onto GDP. This is confirmed by the Significance $F$ indicator, which is less than 0.05 (as the regression was performed with a confidence interval of 95\%). Likewise, both variables in the model are significant, as indicated by the t-Stat indicator, which is less than 0.05 for both variables, therefore indicating a high level of their significance in the model. The regression parameters confirm the reliability of the regression model. Table 3 shows the regression statistics and the evaluation of the regression model.

Table 3. Regression statistics

\begin{tabular}{|c|c|c|c|c|c|c|}
\hline \multicolumn{2}{|c|}{ Regression Statistics } & & & & & \\
\hline Multiple R & 0,8265 & & & & & \\
\hline R Square & 0,6831 & & & & & \\
\hline Adjusted R Squ & 0,6514 & & & & & \\
\hline Standard Error & $1.405 .413 .676,33$ & & & & & \\
\hline Observations & 12 & & & & & \\
\hline \multicolumn{7}{|l|}{ ANOVA } \\
\hline & $d f$ & SS & MS & $F$ & Significance $F$ & \\
\hline Regression & 1 & 42.570 .510 .236 .511 .800 .000 & 42.570 .510 .236 .511 .800 .000 & 21,55264 & 0,000918511 & \\
\hline Residual & 10 & 19.751 .876 .016 .101 .900 .000 & 1.975 .187 .601 .610 .190 .000 & & & \\
\hline \multirow[t]{2}{*}{ Total } & 11 & 62.322 .386 .252 .613 .700 .000 & & & & \\
\hline & Coefficients & Standard Error & tStat & P-value & Lower 95\% & Upper $95 \%$ \\
\hline Intercept & $9.405 .549 .060,18$ & $1.607 .133 .222,96$ & 5,85 & 0,00 & $5.824 .633 .085,79$ & $12.986 .465 .034,58$ \\
\hline GDP & 0,2023 & 0,0436 & 4,6425 & 0,0009 & 0,1052 & 0,2993 \\
\hline
\end{tabular}

Source: Author's own processing in MS Excel software 
The regression model shows that if the M2 monetary aggregate equals zero, then GDP is about 9 billion USD. If M2 would be increased by 1 million, the GDP increases by about 200 thousand USD. That is, if the M2 is increased by 1 billion, the GDP is increased by about 202 million USD. The obtained correlation and regression results indicate that the currency boards have a positive impact on GDP, and as such does not represent an obstacle to economic growth. Therefore, the fundamental hypothesis is accepted.

\section{Conclusion}

The aim of this research was to assess and evaluate whether the Central Bank of Bosnia and Herzegovina operating on the currency boards' principle is actually in the function of development of the national economy or is a limitation to such development. The research was based on a comparison of monetary, macroeconomic and foreign trade position indicators of the Southeast Europe countries, with the focus on the economy of Bosnia and Herzegovina, which applies the currency boards' policy.

The conclusions obtained by analysing and comparing the data on real GDP trends suggest that the currency board's policy was not a constraint on economic growth, measured against the real GDP growth, since the growth trend recorded in countries with the currency boards was in line with the trend observed in other SEE countries. The results of the survey show that the currency boards are not a limiting factor of development. In order to further test the findings obtained by the method of correlation and regression for Bosnia and Herzegovina, it has been proven that the currency boards, expressed through foreign exchange reserves and the broadest monetary aggregate, positively influences the economic growth expressed through GDP.

Ultimately, it is concluded that the currency boards do not constitute a limitation on development, but that it establishes the stability required by small and open economies such as Bosnia and Herzegovina. It is questionable whether the inflation and monetary and macroeconomic stability in Bosnia and Herzegovina with its currency boards, during the dominant crisis periods and distinctive shocks, such as those recorded during 2008/09, would have been sustainable, had the currency boards' policy not been applied

\section{References}

[1] J. Schwartz, Currency boards: their past, present, and possible future role, in: CarnegieRochester Conference series on public policy, North-Holland, 1993, vol. 39, pp. 147-187.

[2] J. Hawkins, Currency boards: traditional, modern and virtual, in: Australian Conference of Economists, 2019.

[3] Ghosh, AM. Gulde, H. Wolf, Currency Boards, in: S. Battilossi, Y. Cassis, K. Yago (Eds.), Handbook of the History of Money and Currency, Springer, Singapore, 2020, https://doi.org/10.1007/978-981-13-0596-2_38.

[4] M. Casmilleri Gilson, Policy pre-commitment and institutional design: A synthetic indicator applied to Currency Boards, OECD, ECO/WKP (2002)16, 2002.

[5] S. Kurt, Currrency Boards, George Mason University, Fairfax, Virginia, 1992.

[6] S. Gedeon, The Political Economy of Currency Boards: Case of Bosnia and Herzegovina, South East European Journal of Economics and Business, 2010, 5(2), pp. 7-20.

[7] Ghosh, A. Gulde, H, Wolf, Currency Boards: More than a Quick Fix? Economic Policy, 2000, vol. 15, issue 31 .

[8] Kristić, Sustainability of Currency Board Arrangement in Bosnia and Herzegovina, Council of Ministers of Bosnia and Herzegovina, Directorate for Economic Planning, Sarajevo, 2007. 
[9] H. Wagner, Central Banking in Transition Countries, International Monetary Fund Working Paper 98/126, 1998.

[10] Ghosh, A. Gulde, H. Wolf, the Currency Boards: the Ultimate Fix? International Monetary Fund, Working Paper 98/8, 1998.

[11] N. Kamhi, V. H. Deheija, An Assessment of the Currency Board Regime in Bosnia and Herzegovina, unpublished draft, 2005.

[12] N. Božović, Currency Board as a Limitation or Solution for development of Economies of Southeast Europe, Master Thesis, Faculty of Economics, East Sarajevo, Bosnia and Herzegovina, 2018.

[13] N. Roubini, the Case against Currency Boards: Debunking 10 Myths about the Benefits of Currency Board, New York University, Leonard N. Stern School of Business, 1995.

[14] Schwartz, Do Currency Boards Have a Future?, Institute of Economic Affairs Occasional Paper 88, London, 1992.

[15] J. Williamson, What Role for Currency Boards, Policy Analyses in International Economics Series 40, Institute for International Economics, Washington, 1995.

[16] T. J. Balino, C. Enoch, V. Santiprabhob, \& S. Peter, Currency Board Arrangements: Issues and Experiences, IMF Occasional Paper 151, 1997.

[17] Central Bank of Bosnia and Herzegovina, Annual Report, 2017.

[18] Directorate for Economic Planning of Bosnia and Herzegovina, Economic trends for 2017, Sarajevo, 2017.

[19] National Bank of Bulgaria, BNB Annual Report, 2017.

[20] M. Hadžić, L. Barjaktarović, Monetary Economics, Singidunum University, Belgrade, 2015. 